\title{
Smoking and Periodontal Disease in Pregnancy: Another Chance for Permanent Smoking Abstinence
}

\author{
Rajko Igić'1,2, Verica Ž. Pavlić ${ }^{3}$, Vesna Ž. Vujić-Aleksićc, Sanja B. Ilićs \\ ${ }^{1}$ Department of Anesthesiology and Pain Management, Stroger Hospital of Cook County, \\ Chicago, Illinois, USA; \\ 2 Department of Pharmacology, Toxicology and Clinical Pharmacology, \\ University of Banja Luka, Banja Luka, Bosnia and Herzegovina; \\ ${ }^{3}$ Department of Periodontology and Oral Medicine, Institute of Dentistry, Banja Luka, \\ Bosnia and Herzegovina; \\ ${ }^{4}$ Department for Certification, The Republic of Srpska Agency for Certification, Accreditation \\ and Quality Improvement in Health Care, Banja Luka, Bosnia and Herzegovina; \\ ${ }^{5}$ Department of Endodontic, Institute of Dentistry, Banja Luka, Bosnia and Herzegovina
}

\section{SUMMARY}

A number of publications confirm the association between periodontitis and general health. It is widely accepted that maternal periodontitis is a risk factor for adverse pregnancy outcomes, such as preterm birth and preterm low birth weight ( $2500 \mathrm{~g})$. These risks increase further in women who smoke. The aim of this study is to clarify the correlations between periodontitis, smoking and adverse pregnancy outcomes and to emphasize the need for an interdisciplinary approach among health professionals (e.g. gynecologists/obstetricians, family physicians, dentists, periodontists and nurses) in order to reduce such risks. Pregnancy is an ideal time for permanent smoking cessation. This condition provides an important "teachable moment" to motivate smokers to change behavior that increases health risks for both fetus/infant and mother.

Keywords: adverse pregnancy outcomes; periodontal disease; pregnancy; smoking; smoking cessation

\section{INTRODUCTION}

Periodontal disease/periodontitis is chronic inflammatory disease characterized by the destruction of connective tissue attachment and alveolar bone that might eventually lead to teeth loss [1]. It is clinically observed in the form of bleeding and tender gums and redness. Such periodontal changes occur in $65 \%$ to $70 \%$ of pregnant women as gingivitis and in $30 \%$ as periodontitis [2]. Since pregnancy may exacerbate pre-existing periodontal disease, and because periodontal disease may cause adverse pregnancy outcome, this condition requires periodontal treatment.

Smoking also presents a maternal risk factor, especially during time of delivery. It is well known that smoking increases the risk of pul- 
monary and cardiovascular complications and impairs tissue healing. Smoking cessation programs delivered in primary and specialty care settings, particularly by interdisciplinary teams with strong physician and dentist involvement, have proven to be an effective means of helping pregnant women who smoke. Though smoking cessation is among the most widely investigated areas in general health, relatively few studies have focused on interventions that combine health education and pharmacotherapy during pregnancy.

The aim of this short review is to present periodontitis as a risk factor for both fetus and mother; it is a significant dental problem that is potentiated in smokers during pregnancy. In addition we want to find out why a substantial number of women continue to smoke during pregnancy and lactation and suggest how a multidisciplinary approach may enable women to stop smoking within the perinatal period.

\section{ADVERSE EVENTS IN PREGNANCY RELATED TO PERIODONTAL DISEASE}

Pregnant women are particularly susceptible to periodontal disease due to increased hormone levels (estrogen and progesterone) that facilitate bacterial plaque formation, as well as changes in oral flora and a decreased immune response. A lack of routine dental exams and delays in treatment further exacerbate the problem [3]. Alteration of the biochemical composition of saliva induced by maternal hormonal changes also enhances the risk [3]. Periodontitis is classified as a "silent killer", primarily because pregnant women may not experience symptoms of periodontitis until it reaches an advanced disease stage. They may thus ignore the perinatal risk of untreated periodontitis.

Numerous publications on this subject confirm an association between periodontitis and systemic health. Many observational studies in recent years [4-12] strengthen the association between periodontitis and adverse pregnancy outcomes, such as preterm birth (PB), preterm low birth weight (PLBW; $<2500 \mathrm{~g}$ ), small for gestational age (SGA; $<37$ weeks of gestation) and pre-eclampsia. To date, most of the literature indicates a strong relationship between maternal periodontitis and the risk for $\mathrm{PB} /$ PBLW [6-9]. These risks increase further in women who smoke [13]. The accumulated literature indicates that smoking is probably the most important environmental risk factor for periodontitis and suggests that smokers are 2-7 times more likely to develop periodontitis than non-smokers [14]. Since PB is the leading cause of neonatal mortality and morbidity in non-anomalous infants [15], research related to periodontitis, smoking and the risk for $\mathrm{PB}$ has increased interest in the topic.

Periodontal treatment during pregnancy has been shown to be safe and effective, but even so, many dentists are reluctant (without any particular reason) to treat pregnant women [16]. Like other dental procedures, such as diagnostic radiography, dental crown restorations and extractions, periodontal treatment was found to be safest during the second trimester; the time period between the 14th and 20th week is considered ideal [2].

Within the existing studies, there are conflicting results. Several authors noted that periodontal treatment had no effect on $\mathrm{PB}$ and PLBW [17-20], indicating that there is no certainty that treatment of periodontal disease during pregnancy will reduce the risks of $\mathrm{PB}$ and PLBW. However, most authors agree that periodontal treatment in pregnancy is beneficial, and they report statistically significant improvement on the incidence of PB and PLBW following scaling and root planing [21-26].

\section{ADVERSE EVENTS IN PREGNANCY RELATED TO SMOKING}

It is well known that smoking accounts for the single largest modifiable risk of fetal morbidity and mortality through both a direct (fetal) and an indirect (placental) effect [27]. The relationship between maternal smoking (prenatal cigarette smoke exposure), children’s exposure to tobacco use (secondhand smoke) and fetal growth is causal, and it depends on intensity and duration of cigarette smoking.

There are several ways that smoking can influence pregnancy and its outcomes. Pregnant women who smoke are at risk for increased pregnancy complications, such as placental dysfunction (including previa or abruption), risk of ectopic pregnancy, intrauterine death, $\mathrm{PB}$ and PLBW. Nicotine exposure also retards intrauterine growth (IUGR) in various ways, including decreased bone/cartilage growth, decreased cranial diameter and tibia length $[28,29]$.

Tobacco exposure during pregnancy reduces blood flow to the placenta (utero-placental 
insufficiency) [30]. In addition, the current literature suggests that infants delivered from mothers who smoked for part or all of their pregnancies are twice as likely to suffer from sudden infant death syndrome [27]. Mothers who smoke are 1.59 times more likely to deliver a PLBW infant than nonsmokers, and the incidence of decreased IUGR was 2.07 times higher in mothers who smoked [28]. With regard to maternal health, smoking increases the risk of pulmonary and cardiovascular complications and impairs tissue healing if maternal surgery is performed (Cesar section or episiotomy) at delivery.

Finally, at least one study showed that women who smoked during pregnancy had a lower prevalence and shorter duration of breastfeeding than non-smoking mothers (2 vs 11 weeks) [31]. Recent data suggest that prenatal tobacco exposure is consistently associated with inhibition of monoamine oxidase during fetal neurodevelopment [32] and changes in behavior (depression, anxiety and learning disorders) in early childhood through late adolescence [33]. Women whose partners smoked also had a higher risk of having a child with growth retardation [28]. Neonates and children who are exposed to secondhand smoke are at increased risk for developing otitis media, asthma and other respiratory tract infections later in childhood.

\section{SMOKING CESSATION IN PREGNANCY}

There are more than 4,800 compounds in particles and vapor of cigarette smoke [29]. Even though many of these are considered health risk factors, nicotine is the principal psychoactive constituent in tobacco. Nicotine influences the function of numerous neurotransmitter systems (dopamine, norepinephrine, 5-hyroxytriptamine, glutamate, GABA and endogenous opioid peptides), causing many of the subjective, cognitive, and behavioral effects associated with smoking [34].

Nicotine is addictive, which is the main reason that many pregnant women do not quit smoking [29]. Furthermore, nicotine mainly accounts for the craving associated with smoking cessation - the most difficult and aggravating withdrawal symptom that causes relapse even after periods of abstinence [34, 35]. Despite documented evidence that tobacco smoking abstinence during pregnancy significantly ben- efits both fetus and the mother, a substantial number of women continue to smoke throughout pregnancy. Pregnancy Risk Assessment and Monitoring System (PRAMS) published data in 2008 showing that $15 \%$ of pregnant women are smokers, despite knowing the health risks and their intentions to quit.

There are several treatment options, including behavioral and/or pharmacological interventions, to assist pregnant women in overcoming their addiction. Behavioral interventions enhance motivation and support attempts to quit through individual or group counseling, telephone counseling and/or selfhelp [36, 37]. Pharmacological interventions serve to reduce nicotine reinforcement and to minimize the symptoms of withdrawal from nicotine.

Three drugs are currently used as first-line pharmacotherapy for smoking cessation: nicotine replacement therapy - NRT (transdermal patch, chewing gum, nicotine sublingual tablets/lozenges, inhaler and nasal spray), bupropion and varenicline (Table 1). The aim of NRT is to diminish withdrawal symptoms associated with smoking cessation and to help the individual resist the urge to smoke cigarettes $[38,39]$. Although NRT, bupropion and varenicline are widely and successfully used among the general population, there are concerns regarding bupropion and varenicline safety for the fetus [39]. Because behavioral interventions report only modest success rates for quitting, and pharmacotherapy alone does not achieve a substantially higher success rate, a combination of pharmacotherapy and behavioral interventions might be more successful for those pregnant women who are moderate to heavy smokers [36]. Therefore, counseling and other behavioral support systems should be used together with pharmacologic interventions to support smoking abstinence, and use pharmacotherapy before conception. Because the pharmacotherapy can affect an unborn baby, it would be better to quit smoking before the pregnancy [37].

Less studied interventions including hypnosis, acupuncture, aversive therapy, exercise, lobeline (a natural alkaloid), anxiolytics, mecamylamine, opioid agonists and silver acetate have assisted some people in smoking cessation, but none of those interventions provide strong evidence of efficacy. SMS text messaging shows promise for delivering smoking cessation support, but its real efficacy must be evaluated further [40]. 
Table 1. Pharmacologic interventions to assist tobacco cessation

\begin{tabular}{|c|c|c|c|}
\hline Drug & Dose & Duration of therapy & Side effects \\
\hline Nicorette chewing gum & $18-24 \mathrm{mg} /$ day & 8 weeks & Stomatitis, sore throat \\
\hline Bupropion & $150 \mathrm{mg} /$ day $\times 2$ days then $300 \mathrm{mg} /$ day & 8 to 12 weeks & Insomnia, dry mouth, rhinitis \\
\hline Varenicline & $\begin{array}{l}0.5 \mathrm{mg} / \mathrm{day} \times 2 \text { days } \\
\text { twice } 0.5 \mathrm{mg} / \text { day } \times 2 \text { days } \\
\text { then } 1.0 \mathrm{mg} \text { twice a day }\end{array}$ & 8 to 12 weeks & Nausea, insomnia \\
\hline
\end{tabular}

For those patients wanting to quit smoking and who smoke six or more cigarettes/day, the doctors will prescribe medications. For patients smoking 6-9 cigarettes/day, a single medication will be given. For those smoking 10 or more cigarettes/day, a combination of a long acting agent (either bupropion or nicotine patches or chewing gums) with short acting nicotine replacement (lozenge) should be prescribed. These medications are especially needed in the postnatal period for relapse prevention in women who had quit smoking because of pregnancy.

The intensive smoking cessation intervention is based on Self-Determination Theory, which focuses on processes through which people become motivated for initiating new self-beneficial behaviors and maintaining them over time [41]. Personal choice that leads to autonomous self-decision is more effective in achieving desired outcomes than coercion or some external pressure (extrinsic motivation). For many smokers pregnancy stimulates their decision to abstain during the perinatal period and/or to quit smoking permanently. However, such behavioral changes will likely need strong psychological support as well as antismoking pharmacotherapy.

The perinatal period is an excellent opportunity for physicians to help smokers quit permanently. Pregnancy can motivate expectant mothers to change a behavior that increases health risk for both them and their fetus (Figure 1). Unfortunately, only a few physicians take advantage of pregnancy and lactation as a "teachable moment" in smoking cessation counseling. Efforts of medical professionals to encourage temporary or permanent abstinence have produced mixed results. In most smoking cessation programs to date, evaluations are based on self-reported quit rates, but biological validation indicates that these self-reports are often biased. Patients presumably falsify their smoking status to give a more socially desirable answer or to present behavior consistent with a healthier life style. For that reason, it is necessary to rely upon biochemical validation of smoking status before delivery.

Development of intensive intervention to support short term and permanent smoking cessation and the demonstration of its efficacy in clinical trials can motivate health care professionals to help more patients stop smoking pre-operatively. Dentists and periodontists are also encouraged to make smoking cessation counseling as a part of periodontal therapy, especially among pregnant women. The components of intensive intervention include informing the patient of the associated health risks of smoking during the perinatal period, as well as the benefits of smoking abstinence, and pharmacological help for overcoming the withdrawal symptoms [42]. In addition to counseling, we recommend that a physician or dentist-periodontist offer a contract/declaration to the mother-to-be that includes a commitment to quit smoking during pregnancy and lactation (Figure 2). This intervention can motivate abstinence for the purpose of a better pregnancy outcome [42].

Effective practice guidelines for physicians should also include enhanced screening and referral services for preconception and pregnant populations; these would provide health programs to educate women and (if possible) also provide free or affordable oral health care for all pregnant women [14]. A strong inter-

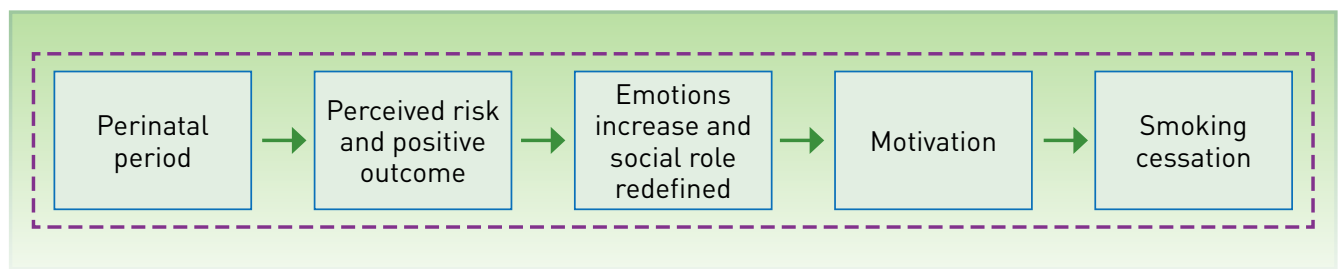

Figure 1. Elements related to smoking cessation 


\section{Declaration of commitment to quit smoking}

I know that smoking during pregnancy and lactation increases the risk for fetus, infant and also for me (mother). Therefore, I declare that I will stop smoking for the entire perinatal period.

During this period, I will receive advices and support from my doctor and his team, including nicotine replacement therapy to overcome craving for cigarettes and telephone calls at my home by members of the team.

When I am admitted for delivery, I will report my smoking behavior (when I smoked the last cigarette, daily recording of my urge to smoke 30 minutes after I wake up in the morning, and how long I used the medications to overcome craving). The doctors will do the biochemical tests on my breath and/or saliva to confirm that I am smoke-free.

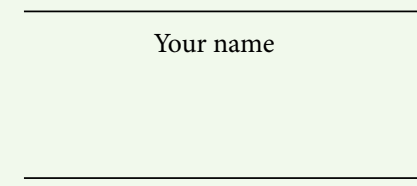

Doctor's name
Date

Date
Note: When you come to the hospital for delivery, please bring this contract that serves as a motivational reminder. It will be kept in the hospital file.

Figure 2. Example of declaration of commitment to quit smoking

disciplinary approach among health care providers (e.g. gynecologists/obstetrician, family physicians and dentists) is important. These professionals should evaluate the medical condition of the patient, especially their smoking status, as a means of assessing the periodontal risk in order to make evidence-based clinical decisions. Physicians should recognize the risks of oral health complications, including both periodontitis and smoking during pregnancy, and they should increase efforts to assess oral health status of their patients, share referrals and recommendations. Working in collaboration with a periodontist, they can offer effective interventions to pregnant woman in their care. In order to reduce smoking in pregnancy, every country should make efforts to eliminate tobacco use (e.g. smoke-free policies, tobacco excise taxes, comprehensive coverage of cessation services and support programs). In addition, anti-smoking campaigns should promote education of children to prevent smoking in this next generation $[43,44,45]$.
Such measures may result in improved health benefits at the population level $[43,44]$. In the Republic of Srpska, approximately $20 \%$ of deliveries in women who smoke require surgical interventions annually. We posit that the combination of gravidity with proximally timed, high intensity smoking-cessation interventions led by healthcare professionals will significantly increase the rate of permanent abstinence.

\section{Conflict of Interest Statement}

The authors certify that there are no potential conflicts of interest.

\section{REFERENCES}

1. Pavlic V, Vujic-Aleksic V, Zubovic N, GojkovVukelic M. Periodontitis and Burger's disease: recent advances. Acta Inform Med. 2013; 21:256-9.

2. Kumar J, Samelson R. Oral health care during pregnancy recommendations for oral health professionals. N Y State Dent J. 2009; 75:29-33.

3. Laine MA. Effect of pregnancy on periodontal and dental health. Acta Odontol Scand. 2002; 60:257-64.

4. Boggess KA, Moss K, Madianos P, Murtha AP, Beck J, Offenbacher S. Fetal immune response to oral pathogens and risk of preterm birth. Am J Obstet Gynecol. 2005; 193:1121-6.

5. Clothier B, Stringer M, Jeffcoat MK. Periodontal disease and pregnancy outcomes: exposure, risk and intervention. Best Pract Res Clin Obstet Gynaecol. 2007; 21:451-66.

6. Madianos PN, Bobetsis GA, Kinane DF. Is periodontitis associated with an increased risk of coronary heart disease and preterm and/or low birth weight births? J Clin Periodontol. 2002; 29:22-36.

7. Khader YS, Ta'ani Q. Periodontal diseases and the risk of preterm birth and low birth weight: a meta-analysis. J Periodontol. 2005; 76:161-5.

8. Sacco G, Carmagnola D, Abati S, Luglio PF, Ottolenghi L, Villa A, et al. Periodontal disease and preterm birth relationship: a review of the literature. Minerva Stomatol. 2008; 57:233-46, 246-50.

9. Vergnes JN, Sixou M. Preterm low birth weight and maternal periodontal status: a meta-analysis. Am J Obstet Gynecol. 2007; 196:135.e1-7.

10. Offenbacher S, Boggess KA, Murtha AP, Jared HL, Lieff S, McKaig RG, et al. Progressive periodontal disease and risk of very preterm delivery. Obstet Gynecol. 2006; 107:29-36.

11. Offenbacher S, Jared HL, O'Reilly PG, Wells SR, Salvi GE, Lawrence HP, et al. Potential pathogenic mechanisms of periodontitis associated pregnancy complications. Ann Periodontol. 1998; 3:233-50.

12. Dörtbudak O, Eberhardt R, Ulm M, Persson GR. Periodontitis, a marker of risk in pregnancy for preterm birth. J Clin Periodontol. 2005; 32:45-52.

13. Marlow SP, Stoller JK. Smoking cessation. Respir Care. 2003; 48:1238-54; discussion 1254-6. 
14. Breedlove G. Prioritizing oral health in pregnancy. Kans Nurse. 2004; 79:4-6

15. Boutigny H, Boschin F, Delcourt-Debruyne E. Periodontal diseases, tobacco and pregnancy. J Gynecol Obstet Biol Reprod (Paris). 2005; 34:3S74-83.

16. Livingston HM, Dellinger TM, Holder R. Considerations in the management of the pregnant patient. Spec Care Dentist. 1998; 18:183-8.

17. Michalowicz BS, Hodges JS, DiAngelis AJ, Lupo VR, Novak MJ, Ferguson JE, et al. Treatment of periodontal disease and the risk of preterm birth. N Engl J Med. 2006; 355:1885-94

18. Boggess KA. Treatment of localized periodontal disease in pregnancy does not reduce the occurrence of preterm birth: results from the Periodontal Infections and Prematurity Study (PIPS). Am J Obstet Gynecol. 2010; 202:101-2.

19. Newnham JP, Newnham IA, Ball CM, Wright M, Pennell CE, Swain J, et al. Treatment of periodontal disease during pregnancy: a randomized controlled trial. Obstet Gynecol. 2009; 114:123948.

20. Uppal A, Uppal S, Pinto A, Dutta M, Shrivatsa S, Dandolu V, et al. The effectiveness of periodontal disease treatment during pregnancy in reducing the risk of experiencing preterm birth and low birth weight: a meta-analysis. J Am Dent Assoc. 2010; 141:1423-34.

21. López NJ, Smith PC, Gutierrez J. Periodontal therapy may reduce the risk of preterm low birth weight in women with periodontal disease: a randomized controlled trial. J Periodontol. 2002; 73:911-24.

22. López NJ, Da Silva I, Ipinza J, Gutiérrez J. Periodontal therapy reduces the rate of preterm low birth weight in women with pregnancy-associated gingivitis. J Periodontol. 2005; 76:214453.

23. Offenbacher $S$, Lin D, Strauss R, McKaig R, Irving I, Barros SP, et al. Effects of periodontal therapy during pregnancy on periodontal status, biologic parameters, and pregnancy outcomes: a pilot study. J Periodontol. 2006; 77:2011-24.

24. Jeffcoat M, Parry S, Sammel M, Clothier B, Catlin A, Macones G. Periodontal infection and preterm birth: successful periodontal therapy reduces the risk of preterm birth. BJOG. 2011; 118:250-6.

25. Di Mario S, Spettoli D, Alessandrini C, Erenbourg A, Ronfani L, Basevi V. Periodontal infection and preterm birth: successful periodontal therapy reduces the risk of preterm birth. BJOG. 2011; 118:635; author reply 635-6.

26. George A, Shamim S, Johnson M, Ajwani S, Bhole $S$, Blinkhorn A, et al. Periodontal treatment during pregnancy and birth outcomes: a meta-analysis of randomized trials. Int J Evid Based Healthc. 2011; 9:122-47.

27. Salihu HM, Wilson RE. Epidemiology of prenatal smoking and perinatal outcomes. Early Hum Dev. 2007; 83:713-20.

28. Horta BL, Victora CG, Menezes AM, Halpern R, Barros FC. Low birthweight, preterm births and intrauterine growth retardation in relation to maternal smoking. Paediatr Perinat Epidemiol. 1997; 11:140-51.

29. Feltes BC, Poloni Jde F, Notari DL, Bonatto D. Toxicological effects of the different substances in tobacco smoke on human embryonic development by a systems chemo-biology approach. PLoS One. 2013; 8:e61743.

30. Dempsey DA, Benowitz NL. Risks and benefits of nicotine to aid smoking cessation in pregnancy. Drug Saf. 2001; 24:277-322.

31. Giglia R, Binns CW, Alfonso H. Maternal cigarette smoking and breastfeeding duration. Acta Paediatr. 2006; 95:1370-4.

32. Baler RD, Volkow ND, Fowler JS, Benveniste H. Is fetal brain monoamine oxidase inhibition the missing link between maternal smoking and conduct disorders? J Psychiatry Neurosci. 2008; 33:187-95.

33. Herrmann M, King K, Weitzman M. Prenatal tobacco smoke and postnatal secondhand smoke exposure and child neurodevelopment. Curr Opin Pediatr. 2008; 20:184-90.

34. Doherty K, Kinnunen T, Militello F, Garvey A. Urges to smoke during the first month of abstinence: relationship to relapse and predictors. Psychopharmacology. 1995:119: 171-8.

35. Igić R. [Health and smoking]. Lijec Vjesn. 1987; 109:409-17.

36. Einarson A, Riordan S. Smoking in pregnancy and lactation: a review of risks and cessation strategies. Eur J Clin Pharmacol. 2009; 65:325. 30.

37. Stead LF, Lancaster T. Combined pharmacotherapy and behavioral interventions for smoking cessation. Cochrane Database Syst Rev. 2012; 10:CD008286.

38. Silagy C, Lancaster T, Stead L, Mant D, Fowler G. Nicotine replacement therapy for smoking cessation. Cochrane Database Syst Rev. 2001; 3:CD000146.

39. Osadchy A, Kazmin A, Koren G. Nicotine replacement therapy during pregnancy: recommended or not recommended? J Obstet Gynaecol Can. 2009; 31:744-7.

40. Naughton F, Jamison J, Sutton S. Attitudes towards SMS text message smoking cessation support: a qualitative study of pregnant smokers. Health Educ Res. 2013; 28(5):911-22.

41. Ryan RM, Deci EL. Self-determination theory and the facilitation of intrinsic motivation, social development, and well-being. Am Psych. 2000; 55:68-78.

42. Igić R. Doctors and smoking. Med Pregl. 2000; 53:117-27.

43. Igić R. January 31 - a day without cigarettes. Med Pregl. 2000; 53:105.

44. Žižić-Borjanović S, Igić R. Characteristics of the smoking campaign in Serbia and Montenegro. Arch Oncol. 2005; 13:93-4.

45. Žižić-Borjanović $S$, Jerinić $M$, Igić R. Twenty five years of antismoking movement started by medical students: some further goals. J BUON. 2007; 12:181-4. 


\title{
Pušenje i parodontopatija u trudnoći: dodatna prilika za potpuni prestanak pušenja
}

\author{
Rajko Igić1,2, Verica Ž. Pavlićs ${ }^{3}$, Vesna Ž. Vujić-Aleksić 4 , Sanja B. Ilić ${ }^{5}$ \\ ${ }^{1}$ Odjel za anesteziologiju i kontrolu bola, Bolnica „Stroger“ Okruga Kuk, Čikago, Ilinois, \\ Sjedinjene Američke Države; \\ ${ }^{2}$ Odjel za farmakologiju, toksikologiju i kliničku farmakologiju, Univerzitet u Banjoj Luci, Banja Luka, \\ Bosna i Hercegovina; \\ ${ }^{3}$ Odjel za parodontologiju i oralnu medicinu, Zavod za stomatologiju, Banja Luka, Bosna i Hercegovina; \\ ${ }^{4}$ Odjel za sertifikaciju, Agencija za sertifikaciju, akreditaciju i unapređenje kvaliteta zdravstvene zaštite \\ Republike Srpske, Banja Luka, Bosna i Hercegovina; \\ ${ }^{5}$ Odjel za endodonciju (bolesti zuba), Zavod za stomatologiju, Banja Luka, Bosna i Hercegovina
}

\section{KRATAK SADRŽAJ}

Veliki broj publikacija je potvrdio uzajamnu povezanost parodontopatija sa zdravljem osoba. Naime, danas je opšte prihvaćena činjenica da je parodontopatija kod trudnica povezana s neželjenim ishodima trudnoće, i to prvenstveno s prevremenim porođajem i malom težinom bebe na rođenju (do 2500 g). Ovi neželjeni ishodi su svakako veći kod trudnica koje puše. Cilj ovog rada je bio da se ukaže na povezanost parodontopatija, pušenja i neželjenih ishoda trudnoće, te podstakne interdisciplinarni pristup (ginekologa-akušera, porodičnih lekara, stomatologaparodontologa i medicinskih sestara) u nastojanjima da se taj rizik smanji. Ubeđeni smo da je trudnoća u životu svake žene koja puši idealno vreme za donošenje odluke o potpunom prestanku pušenja. Trudnoća je i prilika za podsticaj i motivisanje pušača na promenu stila života u mnogo zdraviji, kako za novorođenče, tako i za samu majku.

Ključne reči: neželjeni ishodi trudnoće; parodontopatija; trudnoća; pušenje; odvikavanje od pušenja 